\title{
Ambivalent Clio: J. M. \\ Coetzee's In The Heart of the Country and Wilson Harris's Carnival
}

\section{Hena Maes-Jelinek}

University of Liège, Belgium

History (or if you prefer: folly, courage, pride, suffering) only leaves behind it a residue abusively confiscated, disinfected and finally made palatable for the use of approved handbooks and families with a pedigree... But in fact what do you know?

Claude Simon, The Flanders Road

History is just as light as the life of the individual, unbearably light, light like . . flying dust, like a thing that will disappear tomorrow.

Milan Kundera, The Unbearable Lightness of Being

These quotations clearly express the mystery of history and the scepticism of two major contemporary novelists towards the possibility of fully apprehending, let alone conveying, an objective account of it. The views of a Frenchman and a Czech are not irrelevant to the Commonwealth experience since their countries too have been the theatre of historical disaster in the twentieth century.

The close connection between the writing of history and of fiction hardly needs to be emphasized since, broadly speaking, the raw material of the two kinds of narrative, i.e., human experience, is similar. Although one is supposed to deal with facts and the other with their imaginative interpretation, both are strongly influenced by prevailing social, political and philosophical attitudes. To the historian's conviction in the nineteenth century that he presents historical events objectively, corresponds the generally omniscient narrator of nineteenthcentury fiction who also believes that his uniform vision of reality is the true one. Then came the view expressed by Croce and Collingwood, among others, that the reconstruction of the past could not be dissociated from the subjective view of the historian influenced by the problems of his own time. They acknowledged that historiography meant evaluation and interpretation as much as the reconstruction of events. Another 
historian went so far as to say that 'history is 'made' by nobody save the historian: to write history is the only way of making it" ". ${ }^{2}$ There is only one step from this position to the structuralist assertion that history too is a text like all other forms of reality and that it is therefore a fiction in the same sense as a novel is.

I don't think that the writers (even experimental novelists) who make us intensely aware of the impact of history on individual lives follow philosophers or critical theorists the whole way in this direction. To be aware that men's perception of history, whatever its influence, is necessarily subjective and partial is one thing; to consider it as "deconstructionable" discourse for which only the free play of other discourses, even non-authoritarian ones, are to be substituted is another. As David Lodge put it, "History may be, in a philosophical sense, a fiction, but it does not feel like that when . . somebody starts a war" " Since an intense concern for history and its catastrophic effects lies at the centre of most great twentieth-century novels, there is little doubt that Lodge's view is shared by a majority of writers. But there have been very different ways of reacting to catastrophic events. When in Kundera's first novel, The Joke, the major character asks "'What if history plays jokes?" implying that man has no control over his destiny, he may not be far from sharing the view of American post-modernists, many of whom seem to think that history can only be treated in "comic or apocalyptic ways". "At another extreme Georges Steiner's assertion that language can no longer express the world of history is well known, although he has more recently suggested that tragic history continues to inspire the best fiction.

If history is not a fiction, it has always stimulated the creation of new fictional forms which reflect the writers' perception of the way in which, to paraphrase Croce, history "vibrates" in present situations. My concern here is with novels which do not merely reconstruct events, however imaginatively, but recreate the enigma of their origin and of the motives that provoked them. Such fiction starts from the assumption that history and its causes are as complex and mysterious as individual human behaviour. ${ }^{6}$ In Simon's The Flanders Road the leitmotiv "How are we to know?" punctuates each episode and repeatedly questions the given version of apparently objective facts. In Kundera's novel mystery is suggested metaphorically by a woman painter who criticizes the realistic style she was taught in the Prague academy and explains that she used to trick her teachers by enlarging a spot of colour into a fissure, like the torn canvas of a theatre scene, revealing something mysterious or abstract in the background: "In front was the intelligible lie, and behind the incomprehensible truth',?
Wilson Harris expresses a similar interest in the enigmatic dimension of history when he writes that "we live in a civilization that has created the masks, the furnishings, the apparatus of the past in its museums but has lost the qualitative mystery that lies, for example, within allegory and epic". 8 A vision of history inspired by a conviction that truth is complex and mysterious naturally leads to a questioning of, and inquiry into, the apparent reality and goes together with a transformation of the traditional forms of fictional exploration. The two novels I shall discuss, J. M. Coetzee's In the Heart of the Country and Wilson Harris's Carnival are of this kind. They are extremely different in form and content, yet both put forward the idea that history may consist in a series of disasters, but it also offers possibilities of fulfilment to the imagination capable of perceiving them, althou gh Coetzee suggests this implicitly and ad absurdum through the failure of his heroine to take advantage of such possibilities. Both writers, however, illustrate the need for dialogue and for the kind of fiction which the Russian critic Mikhail Bakhtine called more than fifty years ago the "polyphonic novel" . "His notion of "plurivocity", i.e., the movement, exchange and the always open, always unfinished dialogue between the consciousness of characters and between characters and authors, clearly prefigures Wilson Harris's "multi-voiced imagination",

In order to express this plurivocity, or in Coetzee's case the need for it, the two writers revert to allegory, which may seem paradoxical since in the past this form was often associated with a homogeneous or at least a collectively accepted set of values ${ }^{10}$ and was fairly predictable in its development. But, as Harris's remark quoted above indicates, there is on the second or even deeper levels of meaning in allegory an enigma or mysterious element which, in the fiction we are considering, takes two different forms: that of the mystery inherent in history, and the mysterious or unknown other(s) with whom a dialogue must be created in order to generate plurivocity. Coetzee's novel comes closest to the traditional form of allegory, although it lacks some of its major symbols like the journey or quest as a process of learning. It might be argued that Magda's soliloquy is precisely that. She does envisage such a quest but its possibility is ruled out by her incapacity to achieve consciousness, to learn and change, or by her determination not to do so or both. If, she says, "the road goes nowhere day after day . . . then I might give myself to it". ".

Magda, the heroine, lives a completely isolated and boring existence with her authoritarian father " in the heart of the country", South Africa. Imprisoned in this uneventful life, locked into a love/hate relationship with her father, she twice pictures herself killing him out of jealousy, 
first for his fictitious sensuous new bride, then for the coloured servant's real young bride. What other events are narrated, such as the different versions of her rape by Hendrick, the servant, her affair with him, his running away for fear of being accused of the father's murder, all seem fantasies of frustrated human relationships. At the end of the novel Magda still looks after her father, who has retreated even further into himself, and communication between them is more impossible than ever.

In spite of its vivid evocation of concrete life on the farm,$^{12}$ the narrative is entirely self-reflexive. As the I-narrator, Magda is "a poetess of interiority" (p. 35) who creates herself through words: "I create myself in the words that create me" (p. 8) or "I make it all up in order that it shall make me up' ' (p. 73). It not only suggests that she is responsible for what she is but that to her, and possibly at a further remove Coetzee, language is life, it is reality. Magda is aware of the pitfalls of this equation and fears at times that the very ground under her might turn into a word (p. 62), although words are clearly a refuge for her. Coetzee, himself a linguist, comes very close to post-structuralist theories of language. Even so, I would suggest that Magda's use of language shows white South Africa getting drunk on words but incapable of saving action. She is indeed torn between an impulse to act and her obsession with words. Her retreat into language is both a substitute for action and a unique but tragically aborted opportunity to transform her existence through a new vision. She says at the outset, we "dream allegories of baulked desire such as we are blessedly unfitted to interpret'" (p. 3).

Coetzee's implicit emphasis on the power of language to transform life, a power Magda misuses, is evidence that her long monologue is an allegory of the South African situation; what she calls her own "spinster fate", (p. 4) can be read as a refernce to the isolation of South Africa. She is beset by contradictions. She burns with a desire to communicate with her father, with Hendrick or his wife, Klein Anna; she is aware that communication depends on the creation of a new language (hence a new reality) to replace the "antique feudal language" (p. 43) or to counter her father's "eternal NO"' (p. 16). Yet she also thinks that words alienate, and she remains hopelessly imprisoned in her "'monologue of the self"' (p. 16). Magda is, I think, the white muse of the land, the imagination of white South Africa faced with the need to create a language of communion both within her territory and with the outside world.

I have already suggested that the mysterious element in allegory is represented in both Coetzee's and Harris's novels by an other outside the self with whom a dialogue must be established in order to create a saving "plurivocity". The trouble with Magda is that she both longs for that other and rejects it. True, the other characters too refuse to communicate with her but it is not just her father and the country he represents (p. 71) that will not yield their secrets; reality itself remains enigmatic in spite of Magda's many questions and suppositions. Coetzee dramatizes an existential dilemma through the South African predicament. Magda's narrative shows that there is no such thing as objective reality but her approach to the reality she recreates also proves that she cannot begin to grasp enough of an existence outside herself to come to terms with it. Her attempt at self-knowledge by looking into the mirror ends in self-concern and the rejection of all explanations: "I am beyond the why and wherefore of myself' ' (p. 23). When after this failure she tries looking at the past, the tunnel of her memory turns into the glassy walls of her skull, and she comments "I see only reflections of myself drab and surly staring back at myself" (p. 38). She later admits "my art cannot be the art of memory" (p. 43). This shrinking away from a genuine exploration of history is, I believe, the major reason for her failure to enter into a dialogue with others, ${ }^{13}$ although she feels bitterness at being rejected by it and calls herself a "castaway of history" (p. 135). She does feel nostalgia for a "Promised Land" from which she has been expelled, for the golden age (p. 7) of childhood when she listened with the servants' children to the mythical stories of their old grandfather. But she does not wonder nor regret that Klein Anna is too frightened to talk to her and can only hear "waves of rage crashing in her [Magda's] voice"' (p. 101). Magda thinks then: "This is not going to be a dialogue, thank God . . . I could have burned my way out of this prison, my tongue is forked with fire . . . but it has all been turned uselessly inward . . I have never known words of true exchange" (p. 101, italics mine),

Magda's confession explains why she is, as it were, suspended in her isolation in both space and time, an empty vessel for the words that blow through her like wind (p. 64): "these words of mine come from nowhere and go nowhere, they have no past or future, they whistle across the flats in a desolate eternal present, feeding no one"' (p. 115). And further: "I am the reluctant polestar about which all this phenomenal universe spins. . . . At heart I am still the fierce mantis virgin of yore" (p. 116). It is not just self-centeredness that cuts her off from the community of men and a progressive history. Her incestuous relationship with her father also makes it impossible to create a dialogue with people different from themselves. Sexual relations symbolize her attempts to make contact with people. She twice describes herself labouring under 
her father's weight (pp. 10, 116). But as she acknowledges in Yeatsian accents, no awakening (p. 128), no saviour will redeem their world: "Out of his hole he [the son she might engender] pokes his snout, son of the father, Antichrist of the desert come to lead his dancing hordes to the promised land. .... I struggle to give life to a world but seem to engender only death" (p. 10).

At the end of the novel Magda asks "Where, unless compassion intervenes, does the round of vindictiveness end?"' (p. 130). The compassion, however, is all Coetzee's, for her mixture of understanding and self-deceptiveness and for her deep attachment to "the beauty of this forsaken world" (p. 138). After failing to introduce a dialogue into it, she also fails to make contact with the outside world through the voices she hears from the sky, voices which moralize but are indifferent to her fate. So she still lives with her father, the authority and the law, now blind and deaf, an enduring silent monolith whom she carries and supports, yet would really have to kill in order to be reborn. If, as I suggested, she is the white muse of the land, she is, to use a Harrisian expression, a tragically "blocked muse". ${ }^{14}$ She is still convinced that she lives in paradise but in her own words it has become a "petrified garden" (p. 139), the concrete equivalent of the "stony monologue" (p. 12) she has conducted throughout.

By contrast, the child who appears in the arms of Amaryllis, the Inarrator's wife, at the end of Carnival ${ }^{15}$ represents the transformation of vindictiveness into hope, Harris's unquenchable faith in the capacity of the human imagination to retrieve the seeds of a fruitful union between the antagonists of historical confrontations. As the narrator, Jonathan Weyl, says, "Every puppet of disaster moves in parallel with a spark of redemption, the spark of succession" (p. 171). This is not a blindly optimistic comment, for Harris shirks none of the horrors of history; it is inspired by a philosophy and aesthetic vision once more dazzingly couched in a narrative enacting a "twentieth-century divine comedy of existence"' (p. 43).

"Divine Comedy" immediately brings to mind Dante's allegory, which indeed served as a blueprint for the novel though one that Harris transforms radically. A basic feature of his fiction has always been the transformation of conventionalized or static forms of being and of traditional narrative. He now shows what a malleable form allegory can be. He uses most of its usual constituents, king and queen, knights and ladies, confrontations with beasts and dragons, animal heraldry, but these are essentially living and protean metaphors. His major theme, the collision between metropolitan and colonial worlds, christian and pagan, is explored in a quest journey involving characters who repre- sent ambivalent attitudes: Everyman Masters is a callous overseer in New Forest (obviously Guyana), the Dantesque New World Inferno, but also a consenting dweller and explorer of the London Factory underworld, while his cousin Thomas represents both doubt and revolutionary spirit. Uncertainty and terror, insensitiveness and obliviousness are equally personified, while both Masters and his counterpart, the Carnival Czar Johnny, are at one stage moved by "Diseased Ambition" (p. 29), a desire "to master a universe that has despoiled one" (p. 26), which suggests that they are both victims and victimizers, at least potential ones. Such ambivalence - contained in Everyman Masters' very name - is but one example among many of the ways in which the novel modifies approaches to life and fiction, particularly allegory. There is a level at which the characters progress, like Dante, from Inferno through Purgatory to Paradise but each phase or state is indissociable from its opposite. So in New Forest, the plantation or colonial Inferno, the "Inferno of history"' (p. 21), Aunt Alice's tears "water the rose garden of paradise" (p. 44), while the state of paradise achieved by Jonathan and Amaryllis in the last chapter of the novel is dearly paid for by Masters' descent into the underworld. At a deeper level there is no regular progress from the depths to the heights but a penetration through the gateway into the underworld and the overworld. As Harris himself has suggested, Inferno, Purgatorio and Paradiso are not absolute and separate categories. These are altered in the narrative "to overlap and penetrate one another in subtle degrees'. ${ }^{16}$

The narrative covers over fifty years from 1926 to 1982 , crucial years in the twentieth century which, as Masters says, will be remembered as a "tormented colonial age" (p. 36). All major episodes involve a murder, premeditated or involuntary, committed out of love or of jealousy, or as an unconscious exploitation and devouring of others. The novel opens with the "second death" of Everyman Masters in London in 1982, stabbed by an unknown visitor as he was stabbed in 1957 by a jealous though mistaken husband in New Forest. Each death is, in fact, an occasion for self-analysis and revision of the past. Chronological time and events are evoked with precision but only as frames through which Jonathan freely travels back and forth in imagination. So that links and parallels emerge between events and characters which at first seem to have little in common. For example, both the false shaman whom Masters escapes from as a child on the New Forest beach and the mysterious assassin yet also benefactor he pursues as an old man in London are linked with the mysterious shadow, the ambivalent presence or hidden force all Harris's protagonists contend with. Young Thomas's murder of the Carnival king Johnny; the 
failure of Martin Weyl, Jonathan's father and a lawyer, to save the matricide Amerindian prince; Martin's own accidental death which cuts short his attempt to persuade others of the saving reality of the "savage heart" ; all illustrate the "abortion of an age" (p. 29). Yet the saving element in this failure comes to light as Masters recalls that when his mother was pregnant with him by a white man and contemplated an abortion, he was saved from it by his coloured legal father. By setting aside his pride and insisting that she keep the child, even though this meant for him putting on "the mask of the cuckold" (p. 29), he expressed a "spirit of care" (p. 29) which brought about the "conversion of humiliation into the genius of love" (p.30). ${ }^{17}$

Each element of life, and correspondingly each metaphor in the narrative, is thus seen to contain various, sometimes antithetical, possibilities: anger is destructive but can also be therapeutic, fire consumes yet also regenerates and fertilizes (p. 44). The central feature of the novel is reversibility, a shift from the negative or destructive pole to the creative one, just as the knife, the instrument of so many murders, turns into "seed" (pp. 86 and 87). Another striking transformation of the semantic content of a major metaphor occurs when the destructive "'Trojan"' horse responsible for Martin's death and for the droughtgarden ("Purgatory's belly") in which the colonial people are trapped, later becomes "Christ's Trojan donkey", a striking image merging catastrophic conquest with the possibility of resurrection. It also becomes the seat of the "complex marriage of cultures" (p. 124) Jonathan and his wife achieve. So while In the Heart of the Country is a confession of despair in which possibilities of change are defeated by the protagonist, Jonathan's "reversible fiction' (p. 90), and at a further remove Harris's, envisions what he calls a "translation of the wounds of humanity" (p. 31). This transfiguration, Harris has always insisted, is the specific role of fiction.

Jonathan differs from Magda in another way. While she keeps saying "I am I"' (see p. 5), she also complains that her "monologue of the self is a maze of words out of which [she will] not find a way until someone gives [her] a lead'" (p. 16). Jonathan, on the contrary, contains many others, particularly the guides who lead him into the labyrinth of history. Everyman Masters is the major guide but all the figures of the past are equally helpful as their motives and the mystery of their behaviour are partly clarified through the dialogic reconstruction of Masters and Jonathan. The narrative really consists in attempting to draw increasingly closer to the mysterious origins of actions, and some destructive forms of behaviour (like Thomas's unpremeditated murder of Johnny in an attempt to protect Johnny's wife) turn out to have been provoked by the "profoundest desire to give, to save, and receive nothing in return" (p. 85). The "genius of love", as Masters calls it, is "a major self-reversible element in all revolutions"' (p. 85).

In spite of the partial elucidation of their motives, the many guides Jonathan encounters in his exploration of the past also have about them an aura of mystery which he can only partly unravel. Significantly, they all belong to the colonial world, some of them even to a savage or primitive world, in much the same way as Friday is Crusoe's guide in Michel Tournier's novel Vendredi ou les limbes du Pacifique. They correspond to the "character-masks" who animate the "carnival of history" (pp. 13, 147, 164) which recreates itself, "gestates"' (p. 26) through Jonathan. There is now a considerable literature on the liberating power of Carnival. Mikhail Bakhtine was a precursor on this subject also since he showed in a famous essay on Rabelais ${ }^{18}$ that laughter and popular culture are the carnivalesque elements that free literature from a hierarchical and static vision ${ }^{19}$ and gave rise to the novel as a form which "eternally seeks, analyses itself and questions its acquired forms". ${ }^{20}$ Carnival, a major cultural phenomenon in the Caribbean, has now been transplanted to Britain with West Indian immigration. Harris uses it as a metaphor for his open vision of history and of existence in general, as well as for his conception of fiction as a "double writing" process. As a mere instrument of protest against tyranny, Carnival can harden into sterile opposition as when Czar Johnny and Charlotte Bartleby, both "crabs" of a sort are caught in "the mutual devouring principle within a chained civilization" (p. 52). But Carnival usually celebrates the end of the old world and the birth of a new one symbolized by the death of an old king who must make way for the young. In this sense Harris's novel is an allegory of the death of Empire, which brings to light the uncertainty and terror that preside over the coming of a new age. This is clearly relevant to the South Africa Coetzee portrays. Masters is the dying god or king who must learn "the art of dying" (p. 11), and we may think he succeeds in doing so since he is the putative father of the child conceived by the woman responsible for his death. The child represents the new spirit and the new kind of fiction ${ }^{21}$ that began to gestate with the reconstruction of history.

As a metaphor for Harris's ambivalent view of existence, Carnival encompasses at once temporal, limited, partial realities and a wholeness or "intact reality" (p. 162) sensed or perceived but forever out of reach. Jonathan thinks at one stage: "Carnival time is partial, the past and the present and the future are parts of an unfathomable Carnival whole beyond total capture"' (p. 31), while Masters speaks of a "true life, 
a true spirit, beyond all frames" (p. 108). The "Carnival revolution" (p. 63) Harris presents is therefore a process, a capacity to free oneself from rigid attitudes. It is also "a capacity for shared wounds, shared ecstasies" (p. 11). When Jonathan describes the "reality of paradise" or "intercourse" he and Amaryllis attain, he says:

We lived in yet out of frames, we touched each other yet were free of possession, we embraced yet were beyond the net of greed, we were penetrated yet whole, closer together than we have ever been yet invisibly apart. We were ageless dream. (p. 123)

If, inevitably, Carnival involves the wearing of masks, thus "hides us from ourselves", it also "reveals us to ourselves" (p. 86) and entails a penetration of "many series of inward masks" (p. 43), "the veils within veils within us" (p. 44), or, put differently, of "the extended and multi-layered luminosities of the cosmos" (p.45).

This "far-viewing" (p. 163) also applies to Jonathan's writing process. Again, unlike Magda who creates herself in her monologue, he shows, both in the discursive and the metaphorical texture of the narrative, that he is as much created by the character-masks or guides in dialogue with him as they are by him: "[Masters] and other charactermasks were the joint authors of Carnival and I was their creation" (p. 31). He is both "[Masters'] creation and his father-spirit" (p. 31). He repeatedly insists on this reciprocity and on his role as "fictionparent of generations steeped in the collision of worlds"' (p. 34).

A major achievement of the novel lies in its compelling fusion of vision and form, the re-vision of history and the reflexiveness on the kind of plurivocal fiction that makes this re-vision possible. On the face of it, the "deconstruction" that is a prerequisite to re-vision has a lot in common with the post-structuralist approach to history. But Harris's belief in some intact though unreachable reality (see above), in some mysterious force which he has called "unnameable [moving] centre or unfathomable wholeness",22 is radically different from Derrida's (and many post-structuralists') denial of any centre and his tendency to fall back on the text or on language as the only reality. ${ }^{23}$ Harris's narratives express simultaneously a renewed faith in man and in the capacity of language to transform his consciousness. As Jonathan says, "The Word is the Wound one relives again and again within many partial existences of Carnival"' (p. 13).

\section{NOTES}

1 This paper was read on 20 June 1986 at the ACLALS conference which took place at the National University of Singapore, 16-23 June 1986. The theme of the conference was "The Writer as Historical Witness: the Commonwealth Experience", 2 M. Oakeshott, Experience and its Modes, 1933, quoted by E. H. Carr in What i.s History?, first published in 1961, Harmondsworth: Pelican Books, 1976, p. 22

3 David Lodge, The Novelist at the Crossroads, London: Routledge and Kegan Paul, 1971, p. 33.

4 The phrase is Bernard Bergonzi's, 'Fictions of History', in The Contemporary English Novel, eds. Malcolm Bradbury and David Palmer, Stratford-Upon-Avon-Studies 18 , Edward Arnold, 1979, p. 45.

5 In a talk entitled 'The Muse of Censorship', delivered on 18 July 1984 at the English Studies Seminar organized by the British Council at the University of Cambridge.

6 So is the writing of history, whose alleged objectivity is seriously questioned even in a formally traditional and realistic novel like Angus Wilson's Anglo-Saxon Attitudes, 1956.

7 Milan Kundera, L'insoutenable légèreté de l'être, translated from the Czech by François Kérel, Paris: Gallimard, 1984, p. 84. Translation into English mine.

8 Wilson Harris, Letter to Hena Maes-Jelinek, 7 November 1984

9 Mikhail Bakhtine, Esthétique et théorie du roman, translated from the Russian by Daria Olivier, Paris: Gallimard, 1978, p. 14., Translation into English mine. The first essay in this volume was written in 1924 but was not published until half a century later. The other essays appeared in the late twenties and in the thirties.

10 On this subject see Gay Clifford, The Transformations of Allegory, London: Routledge and Kegan Paul, 1974. However, as the title of the book indicates, the author shows that allegory is not a static form and contains possibilities of transformation.

11 J. M. Coetzee, In the Heart of the Country, first published in 1977, Harmondsworth Penguin Books, 1983, p. 63. All further references are to this edition and given in the text.

12 This is wonderfully rendered in the film adaptation entitled Dust by the Belgian director Marion Hänsel. The film stars Jane Birkin, Trevor Howard and John Matshikiza.

13 Ironically, she calls "dialogue" a conversation in which her father peremptorily questions the black servant (p. 20) who addresses him in the third person as "the baas"

14 Wilson Harris, The Womb of Space, Westport (U.S.A.): Greenwood Press, 1983, Introduction. p. $\mathrm{xx}$.

15 Wilson Harris, Carnival, London: Faber and Faber, 1985. All references are to this edition and given in the text.

16 Interview by Jane Wilkinson, Turin, 29 October 1985, Kunapipi, VIII, 2, 1987, p. 32 .

17 Wilson Harris has explored this "Joseph" role in The Angel at the Gate, London: Faber and Faber, 1982. Interestingly, one of the epigraphs to this novel epitomizes Harris's approach to history in Carnival. It is quoted from Mircea Eliade's 'Shamanism': "The dialectic of the sacred permits all reversibilities; no "history" is final. History is in some measure a fall of the sacred, a limitation and diminution. But the sacred does not cease to manifest itself, and with each new manifestation it resumes its original tendency to reveal itself wholly". From a very different perspective, E. M. Forster makes a similar point in A Passage to India: "The adept may think, if he chooses, that he has been with God, but as soon as he thinks it, it becomes history, and falls under the rule of time" (Penguin edition, p. 283). 18 This was his doctoral thesis completed in 1941 but only published in 1965. For 
a detailed analysis of Carnival in the light of Bakhtine's theories, see Russell McDougall, "Wilson Harris and the Art of Carnival Revolution", to be published in Commonwealth, Essays and Studies (Dijon).

19 On this subject see John Thieme, "The World Turn Upside Down: Carnival Pat terns in The Lonely Londoners", Toronto South Asian Review, 5, 1, Summer 1986.

20 Mikhail Bakhtine, Esthétique et théorie du roman, p. 472. Translation into English mine

21 On the child metaphor in Harris's fiction see Gary Crew's dissertation, The Child Metaphor in the Fiction of Wilson Harris, University of Queensland.

22 Interview by Helen Tiffin, New Literature Review No. 7, p. 24. That Harris thinks the centre is not "still" or static is suggested in an early poem, "In Memoriam 1948', Kyk-Over-Al, 2, 7, December 1948, 6.

In another context Harris refers to an "unstructured mediation between partial systems" or "untamable force", "Carnival of Psyche: Jean Rhys's Wide Sargasso Sea", Explorations, Aarhus: Dangaroo Press, 1981, p. 132

23 See Frank Lentricchia, "The major theme accompanying decentering is that there is nothing outside the text, 'il n'y a pas de hors-texte" " (Derrida's famous statement in Grammatology), although Lentricchia adds that "Derrida is no ontologist of le néant because he is no ontologist", After the New Criticism, London: Methuen, 1983 , pp. $170-171$

\section{Editor's Note}

Volume XXIII, no. 1, will contain an Interview with George Lamming, conducted by Frank Birbalsingh. 